Journal of Educational Method and Technology Vol. 2 No. 2, Agustus 2019

P-ISSN 2622-8459 E-ISSN 2622-8467

http://ejournal.unima.ac.id/index.php/jemtec

\title{
Relationship On Class Management For Learning Achievements Students In Building Engineering Education Department, Faculty Of Engineering, Universitas Negeri Manado
}

\author{
M S S S Tumanduk ${ }^{1}$, R R Oroh ${ }^{2}$ \\ ${ }^{1,2}$ Universitas Negeri Manado, Indonesia \\ corresponding author: ${ }^{1}$ morris_tumanduk@unima.ac.id
}

\begin{abstract}
This study aims to determine whether there is a relationship between classroom management and student achievement in the Building Engineering Education Department, The Faculty of Engineering, Universitas Negeri Manado, and look for obstacles or obstacles that inhibit the success of student learning while looking for efforts to overcome these problems. This research method is correlational research. The results of a simple linear regression analysis of the variables of classroom management and student achievement in the Building Egineering Education Department, Faculty of Engineering, Universitas Negeri Manado obtained the equation of the regression line $\mathrm{y}^{\prime}=34.80+0.42 \mathrm{X}$, which illustrates that if class management increases by one unit, student achievement will increase amounting to 0.361 units. Similarly, the results obtained that the regression model is good enough, because based on the model deviation test shows that the deviation is not significant at the 5\% test level in this case $\mathrm{F}$ (Calculate) $=0.73<\mathrm{F}$ (Table) $=2.43$. Thus, the regression equation above can be used to estimate or predict learning achievement $(\mathrm{Y})$ if class management $(\mathrm{X})$ is known. The results of testing the hypothesis, it is evident that the classroom management variables $(\mathrm{X})$ have a positive and significant effect on student learning achievement at the Building Egineering Education at Universitas Negeri Manado. Based on these results, there is a significant and positive relationship between classroom management and student achievement in the Building Egineering Education Department students at Universitas Negeri Manado.
\end{abstract}

Keywords: Classroom Management; Students; Learning Achievement

\section{Introduction}

Teaching and Learning is the most important activity, because it is through this process that educational goals will be achieved in the form of changes in Student behavior. National Education System Law No. 20 article 3 of 2003, namely: National education aims to develop the potential of students to become people who have faith, devote to God Almighty, noble, healthy, knowledgeable, capable, creative, independent, and become citizens of a democratic and responsible. Students will be motivated to study well, if the lecturer teaches in accordance with Student expectations. But the reality shows, often the lecturer personality in the Teaching and 
Learning Process does not build student learning motivation. Also in the ability of lecturers in classroom management greatly affect student achievement. In the learning process, lecturers have the task to encourage, guide, and provide learning facilities for students to achieve learning objectives. Lecturers have the responsibility to see everything that happens in the classroom to help the development process of students. Class management is a complex matter of behavior, and lecturers use it to create and maintain classroom conditions in such a way that students can achieve teaching goals efficiently and enable them to learn.

Building Engineering Education Department (PTB), Faculty of Engineering, Universitas Negeri Manado is the only State University in Minahasa Regency that has a PTB S1 Study Program, Civil Engineering S1 Study Program, and Architecture S1 Study Program, one of the educational institutions that is expected to be able to prepare ready staff use professional, and produce qualified and skilled personnel in the field of Building / Civil Engineering and Architecture, in fact Student learning achievement is generally low.

The low learning achievement of students is certainly influenced by many factors, both internal, such as intelligence, talent, interest, motivation, maturity, and readiness. While external factors, including lecturer readiness, classroom management, curriculum, teaching methods, and family economics. From these various factors, in the author's observation that the more dominant cause of low student achievement is the ability of lecturers in classroom management. The purpose of this research is to get a picture of the influence between classroom management and student achievement in the Building Engineering Education Department, Faculty of Engineering, Universitas Negeri Manado. As for the benefits of this research are the results of this study, are expected to be particularly useful for improving the learning achievement of the Students of Building Engineering Education Department, Faculty of Engineering, Universitas Negeri Manado, and for improving the quality of education in general.

\section{Literature Review \\ Class Management}

It is undeniable that the classroom is a learning environment that is created based on the collective awareness of a Student community that relatively has the same goal. The similarity of goals is a potential force for classroom management and its actuality is an acceptable learning process (Fathurrohman P, 2011: 103). According to Sudirman N. et al., (1991: 310), that class management is an effort to utilize class potential. Furthermore, Djamarah S.B., and Aswan Zain (2002: 198), asserted that classroom management is an effort deliberately done by the teacher to achieve teaching objectives. Likewise, according to Arikunto S., (1988) in Fathurrohman P., (2011: 103), that classroom management is an effort made by a lecturer to help create optimal learning conditions.

The above understanding shows that there are several aspects that need to be managed synergically, integrated and systemically by the Lecturer, namely:

a. Classroom, showing the limits of the learning environment,

b. Lecturer Efforts, demands for the dynamics of Lecturer activities in anticipating all possibilities that occur in the learning environment,

c. learning conditions, is a limitation of activities that must be realized, and 
Journal of Educational Method and Technology Vol. 2 No. 2, Agustus 2019

P-ISSN 2622-8459 E-ISSN 2622-8467

http://ejournal.unima.ac.id/index.php/jemtec

d. optimal learning, is a measure of the quality of processes that drive the quality of a learning product.

According to Djamarah S.B., and Aswan Zain (2002: 199), that the classroom management conducted by the Lecturer is not without purpose, because there is a purpose that the Lecturer always tries to manage the class, even though sometimes physical or mental fatigue is felt. Lecturers are aware that without managing the class well it will hamper their teaching and learning activities, it is the same as letting the teaching run without bringing results, which takes students from not knowing to knowing, from not understanding to understanding, from not being knowledgeable to being knowledgeable. Class management is intended to create conditions in class groups in the form of a good classroom environment, which allows students to act according to their abilities. Then by managing the product class must be in accordance with the objectives to be achieved.

The purpose of classroom management is essentially contained in the objectives of education. Where in general, the purpose of class management is the provision of facilities for a variety of Student learning activities in the emotional and intellectual social environment in the classroom. The facilities provided enable students to study and work, creating a social atmosphere that provides satisfaction, an atmosphere of discipline, emotional intellectual development and attitude, and appreciation for students, Sudirman N. et al., (1991: 311).

Furthermore, Saud U.S., (2009: 69), detailed the objectives of classroom management, as follows:

a. Encourage students to develop their behavior according to the learning objectives,

b. Helping students stop their behavior that distorts the learning objectives,

c. Control students and learning tools in a pleasant learning atmosphere to achieve learning goals, and Fostering good interpersonal relationships between teachers and students and students and students, so that learning activities become effective.

The problem of class management is not an easy task. Various factors that cause the complexity. In general, the factors that influence classroom management are divided into two groups, namely, Student internal factors and Student extreme factors. Student internal factors are related to emotional, thought, and behavior problems. Student Personalities with their respective characteristics cause students to be from other students individually. The differences between these individuals are seen from biological, intellectual, and psychological differences. While the external factors of students are related to the problem of the atmosphere of the learning environment, placement of students, grouping students, the number of students in the class, and so on. The problem of the number of students in the class will color the dynamics of the class, and the more the number of students in the class, for example 30 people and above tend to be younger in conflict. Conversely, the smaller the number of students in the class tends to be smaller in conflict. As long as there is effort from the Lecturer, the chaos in the classroom can definitely be overcome. It is recognized that, class from time to time, from day to day, today, tomorrow, or the day after tomorrow, always shows a different atmosphere. Yesterday the atmosphere was calm. It might be noisy and hot class today. At times learning goodness Students are disturbed by the coming of disturbances from outside the classroom in various 
forms and types such as there are fires around the school there are thieves in broad daylight, there are collisions of motorized vehicles and so on.

In order to minimize the problem of disruption in classroom management, the principles of classroom management can be used. So it is important for Lecturers to know and master the principles of classroom management which will be described below:

a. Warm and enthusiastic

Warm and enthusiastic are needed in the teaching and learning process. Lecturers who are warm and familiar with students always show enthusiasm in their assignments / activities will succeed in implementing classroom management.

b. Challenge

The use of words, actions, ways of working or challenging materials will increase the enthusiasm of students to learn thereby reducing the possibility of the appearance of deviant behavior and will be able to attract the attention of students, and can control their enthusiasm for learning.

c. Vary

The use of tools or media, or assistive devices, the teaching style of the lecturer, the pattern of interaction between the lecturer and students will compensate for the emergence of disturbances, increase students. Especially if the user varies according to the needs of the moment. The variety in the use of what is mentioned above is the key to achieving effective classroom management and avoiding clumsiness.

\section{d. Flexibility}

Flexibility of lecturers 'behavior to change their teaching strategies can prevent the possibility of emergence of students' disorder and create an effective teaching and learning climate. The flexibility of teaching can prevent the emergence of disturbances such as student commotion, no attention, not pursuing tasks, and so on.

e. Emphasis on the Positive

Basically in teaching and educating, lecturers must explain the positive things and avoid focusing students' attention on negative things. Emphasis on positive things, namely the emphasis done by lecturers on the behavior of students who are positive rather than nagging negative behavior. This emphasis can be done by giving positive mastery, and the lecturers' readiness to avoid mistakes that can interfere with the nets of the learning process.

\section{f. Cultivating Self Discipline}

The ultimate goal of classroom management is that students can develop self discipline. Therefore, the lecturer should always encourage students to implement their own discipline and the lecturer himself should be an example of the return and implementation of responsibilities. So, lecturers must be disciplined in everything if they want their students to be disciplined in everything.

\section{Learning Achievement}

According to Hamalik Oemar (1992: 17), that learning achievement is the result achieved by a student after carrying out a learning process. The results 
achieved will then have a place in the treasury of student knowledge, and each understanding will affect the structure of the treasury as a whole. The same thing as stated by Turang J., (1990: 14), that learning achievement is the appearance of the level of student learning outcomes through an evaluation of learning, in this case students will be able to master more, more critical, more skilled, faster and can complete the task and has a higher value compared to the others.

Furthermore, according to Nurtain and Andi Makhulam (1979: 4), that learning achievement is what is mastered or achieved by individuals who have carried out a certain learning activity and within a certain time span. Meanwhile, Poerwadarminta (1976: 678), stated that achievements are the results that have been achieved, done, done and so on.

From the description above, it can be stated that learning achievement is the result obtained by a student after the student has undertaken a certain learning activity, through an evaluation process. What is achieved by a student after wrestling learning activities are learning outcomes, but not all learning outcomes are said to be good. Because it depends on several factors that directly affect the student. A good evaluation tool is validity and reliability. A teacher will know which programs or procedures may be continued, and which ones are improved and will be abandoned. Thus to determine a person's success in learning can be seen an evaluation or assessment.

\section{Research Method \\ Research Procedure}

This study is a correlational study that aims to find out whether there is a relationship between the independent variables with the dependent variable and the extent of the correlation between the independent variables and the dependent variable based on the correlation coefficient.

\section{Research Variables}

The variables examined in this field of research consisted of 2 variables:

a. Independent variable: Class Management (X)

Class management instruments are developed by arranging items that are based on the indicators of class management variables. For this variable the statement uses a Likert scale. For positive statements, the score is as follows:

Very often $=4$

Often $=3$

Almost never $=2$

Never $=1$

For negative statements the score is contrary to positive statements. The number of items for classroom management instruments is 25 items. The instrument grid can be seen in table 3.1 . 
Table 3.1. Classroom Management Grid.

\begin{tabular}{|c|c|c|c|}
\hline \multirow{2}{*}{ Indikator } & \multicolumn{2}{|c|}{ Nomor Butir } & \multirow[b]{2}{*}{ Jmlh } \\
\hline & Positif & Negatif & \\
\hline Kemampuan Dosen menyiapkan Fasilitas belajar & $1,2,20$ & 3,4 & 5 \\
\hline $\begin{array}{l}\text { Kemampuan Dosen Mengelolah Program Belajar } \\
\text { Mengajar }\end{array}$ & $5,6,22$ & 7,23 & 5 \\
\hline Kemampuan Dosen Mengelolah Kelas & 8,10 & 9,24 & 4 \\
\hline $\begin{array}{l}\text { Kemampuan Dosen Mengelolah Interaksi Belajar } \\
\text { Mengajar }\end{array}$ & 11,13 & 12,25 & 4 \\
\hline $\begin{array}{l}\text { Kemampuan Dosen Menilai Prestasi Belajar } \\
\text { Mahasiswa Untuk Kepentingan Pengajaran }\end{array}$ & 14,16 & 15,21 & 4 \\
\hline Kemampuan Dosen dalam menerapkan disiplin & 17,19 & 18, & 3 \\
\hline Jumlah & 14 & 11 & 25 \\
\hline
\end{tabular}

b. Independent variable: Learning achievement (Y)

Data from the instrument of student achievement is taken through the documentation of the average value of the KHS of Building Engineering Education Department, Faculty of Engineering, Universitas Negeri Manado Students from 2014 to 2017.

\section{Research Model}

The research model can be described as follows:

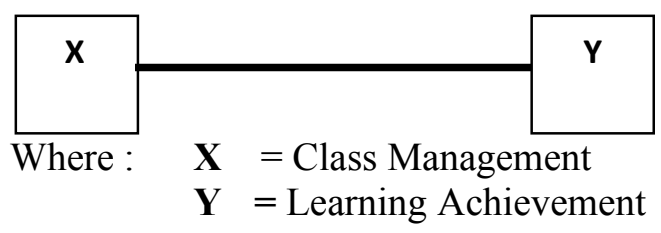

\section{Place and Time of Research}

Research locations in the Building Engineering Education class of 2014 to 2017. The time of research for 4 months from July 2018 to October 2018.

\section{Sampling technique}

The sampling technique in this study is the "Purposive Side Judgemental" technique. In this case, samples are taken based on the considerations that best suit the purpose of the study. Thus the sample taken is all students who are still active in the class of 2014 to 2017.

\section{Data Collection Techniques}

To obtain the data needed in this study, questionnaire and documentation instruments were used, namely classroom management variables using a questionnaire, and learning achievement using KHS score documentation. 


\section{Data Collection Techniques}

For the purposes of analyzing data, a simple linear regression analysis technique is used. with the formula in Sujana (1986: 236), as follows:

$r=\frac{n(\Sigma X Y-(\Sigma X)(\Sigma Y)}{\left.\sqrt{n\left(\Sigma X^{2}\right)}-(\Sigma X)^{2}\right)\left(n\left(Y^{2}\right)-(\Sigma Y)^{2}\right.}$

Correlation analysis is intended to determine the relationship between two variables, in this case the relationship between classroom management $(\mathrm{X})$ with learning achievement (Y).

\section{Results And Discussion}

Regression Coefficient Analysis

From the results of the calculation, the results can be stated as follows: $\mathrm{y}=34.80+0.42 \mathrm{X}$

The results above illustrate that if class management increases by one unit, then the average student achievement will increase by 0.361 units.

\section{Analysis of Variance}

Analysis of variance is carried out with a view to knowing whether the results obtained above, are appropriate so that they can be used to estimate or predict student achievement when class management is known, with results (see Appendix 7.1). These results show that the regression model is good enough, because based on the model deviation test shows that the deviation is not significant at the $5 \%$ test level in this case $\mathrm{F}($ Calculate $)=0.73<\mathrm{F}($ Table $)=2.43$. Thus, the regression equation above can be used to estimate or predict learning achievement (Y) if class management (X) is known. As for the test of the regression model, it shows that the model is real or significant at the 5\% test level, in this case $\mathrm{F}($ Calculate $)=101.45>\mathrm{F}($ Table $)=4.20$.

\section{Correlation Analysis}

Correlation analysis is intended to determine the relationship between two variables, in this case the relationship between classroom management and student achievement, with the following formula:

$$
\begin{aligned}
r & =\frac{n(\Sigma X Y-(\Sigma X)(\Sigma Y)}{\left.\sqrt{n\left(\Sigma X^{2}\right)}-(\Sigma X)^{2}\right)\left(n\left(Y^{2}\right)-(\Sigma Y)^{2}\right.} \\
r & =\frac{26(135499)-(2022)(1733)}{\sqrt{26\left[(159196)-(2024)^{2}\right)\left(26(115811)-(1739)^{27}\right.}} \\
& =\frac{15382}{\sqrt{(42520)(7797)}}=0,85 \\
\mathrm{r}^{2} & =0,8447^{2}=0,71
\end{aligned}
$$

The results above, show that $\mathrm{r} 2=0.71$, this means that the regression model has been able to explain the diversity of student achievement around $71 \%$ or in other words that classroom management contributes to student learning achievement by $71 \%$. 
Journal of Educational Method and Technology Vol. 2 No. 2, Agustus 2019

P-ISSN 2622-8459 E-ISSN 2622-8467

http://ejournal.unima.ac.id/index.php/jemtec

\section{Discussion}

The results of the data description of student achievement scores indicate that of 30 respondents there were 15 or $50 \%$ of respondents included in the category of learning achievement groups below the average., And 15 or $50 \%$ of respondents included in the category of high learning achievement or above average. From the results of the description of student achievement data, the students are generally quite good. The description of the value of class management shows that of the 30 respondents there were 8 or $26 \%$ of respondents included in the category of the class management group below the average, no respondents included in the category of the class management group on average, and 22 or $74 \%$ of the respondents entered into high or above average category. From the results of the data description, it shows that the management of these classes is generally quite high.

Based on the results of hypothesis testing, it is evident that the variables of class management $(\mathrm{X})$ have a positive and significant effect on student achievement, this can be explained as follows: from the results of a simple linear regression analysis of classroom management variables and student achievement in the Building Engineering Education Department, Faculty of Engineering, Universitas Negeri Manado obtained a regression line equation $y=34.80+0.42 \mathrm{X}$, which illustrates that if class management increases by one unit, student achievement will increase by 0.361 units. Similarly, the results obtained that the regression model is good enough, because based on the model deviation test shows that the deviation is not significant at the $5 \%$ test level in this case $\mathrm{F}($ Calculate $)=0.73<\mathrm{F}($ Table $)=2.43$. Thus, the regression equation above can be used to estimate or predict learning achievement $(\mathrm{Y})$ if class management $(\mathrm{X})$ is known. Likewise for the test of the regression model, it shows that the model is real or significant at the $5 \%$ test level, where $\mathrm{F}$ (Calculate) $=101.45>\mathrm{F}($ Table $)=4.20$., With a coefficient of determination of $\mathrm{r} 2=0,7135$, this means that the regression model has been able to explain the diversity of student learning achievement around $71.35 \%$ or in other words that classroom management affects the learning achievement of Building Engineering Education Department, Faculty of Engineering, Universitas Negeri Manado Students by $71.35 \%$.

\section{Conclusions and Suggestions Conclusions}

Based on the research problem, theoretical description as well as the results and discussion, the conclusions from this study can be formulated as follows: that there is a significant and positive relationship between classroom management and student achievement in the Building Engineering Education Department, Faculty of Engineering, Universitas Negeri Manado.

\section{Suggestions}

Considering the findings of this study that there is a significant and positive relationship between classroom management and student achievement in the Building Engineering Education Department, Faculty of Engineering, Universitas Negeri Manado, it is recommended:

1. For lecturer advisors to further enhance their ability to manage classes so that student achievement can improve. 
Journal of Educational Method and Technology Vol. 2 No. 2, Agustus 2019

P-ISSN 2622-8459 E-ISSN 2622-8467

http://ejournal.unima.ac.id/index.php/jemtec

2. Further research is conducted on other factors that are theoretically related and can improve student learning achievement.

\section{References}

Djamarah Syaiful Bahri dan Aswan Zain, 2002, Teaching and Learning Strategies. Rineka Cipta. Jakarta.

Fathurrohman Pupuh dan Sobry Sutikno, 2011, Teaching and Learning Strategies. Refika Aditama. Bandung.

Hamalik Oemar, 1992, Learning Methods and Learning Difficulties. Tarsito. Bandung.

Nurtain dan Andi Makhulam, 1979, PSI Education, SPS IKIP Bandung.

Poerwadarminta W.J.S., 1976, Small Indonesian Dictionary. J.B. Wolters, Jakarta.

Saud Udin Syaefudin, 2009, Teacher Professional Development. Afabeta, Bandung.

Sudirman N. dkk., 1991, Educational Science. Remaja Rosdakerya. Bandung.

Sujana, 1986, Statistics Method. Tarsito. Bandung.

Turang J., 1980, Teacher Modernization and Learning Achievement. Biro Humas IKIP Manado. 